\title{
The Influence of Leadership Styles and Work Motivation on Teacher's Performance
}

\author{
Retno Widia Astuti \\ SMA Negeri 1 Air Kumbang, Indonesia \\ e-mail: rwidia103@gmail.com \\ Happyn Fitria \\ Universitas PGRI Palembang, Indonesia \\ e-mail: happyfitriamufly@ univpgri-palembang.ac.id \\ Rohana \\ Universitas PGRI Palembang, Indonesia \\ e-mail: rohana@univpgri-palembang.ac.id \\ Article History: Received on 18 September 2020, Revised on 26 September 2020, \\ Published on 26 September 2020
}

\begin{abstract}
This study determined the influence of the principal's leadership style and work motivation on the performance of high school teachers. Data in this study were collected through distributing the questionnaires to respondents. The results of the questionnaire were analyzed by using multiple regression analysis through t-test, F-test, and the coefficient of determination. Population in this study was all high school teachers in Air Kumbang sub district of Banyuasin district totaling 85 people. The sampling technique used was saturation. The research sample was 85 high school teachers. The results showed 1) there was a positive and significant effect of leadership style on teachers' performance; 2) there was a positive and significant influence of work motivation on teachers' performance; 3) there was a significant influence simultaneously of leadership style and work motivation on the performance of high school teachers in Air Kumbang sub-district Banyuasin.
\end{abstract}

Keywords: Principal Leadership, Teacher's Performance, Work Motivation

\section{A. Introduction}

The progress and retreat of a nation is largely determined by the quality of the nation's education as stated in the National Education System Law Number 20 Year 2003 Article 3 concerning the functions and objectives of national education. One of the national ideals that must be fight for by the Indonesian people is the effort to educate the nation's life through national education. The role of education is crucial in efforts to achieve these national ideals.

Pursuant to Law Number 20 Year 2003 concerning the National Education System article 39 paragraph 3 states that educators who teach in primary and secondary education units are called teachers. Meanwhile, the task of the teacher as mentioned in article 39 paragraph 2 is to plan and carry out the learning process, conduct mentoring and training and conduct research and community service. 
According to Kristiawan (2018) teacher as educator in carrying out their duties are multi-role that is as an educator, trainer and teacher. The teacher has a very important role, and has responsibility for national education. According to Hasan (2003) Specific criteria that must be owned by the teacher as a professional 1) have a commitment to students and the learning process; 2) mastering the subjects taught and mastering how to teach them to students; 3 ) have responsibility for monitoring student learning outcomes through various evaluation methods; 4) able to think systematically about what he does and learn from the environment of his profession. The importance of the teacher's roles and responsibilities is stated in Law number 14 of 2005 concerning Teachers and Lecturers that the teacher as the manager of learning must be a facilitator, motivator, motivator, learning engineer, and learning inspiration for students.

The importance of the teacher's role in the education system was not as expected, especially in improving the quality of education in Indonesia. UNESCO data in Global Education Monitoring (GEM) Report 2016 explains that the quality of our country's education rank is 10th out of 14 developing countries and the quality of teachers who are the most important component in the world of education rank is 14th out of 14 developing countries in the world. Detik News, Friday 24 November 2017 in Handayani (2020) stated that teachers are required to have performance that can provide and realize the hopes and desires of all parties, especially the general public who have trusted schools and teachers in fostering students.

In general, the quality of education as a benchmark of success is shown by teacher performance. According to Rivai (2005: 14) performance is a translation of the word performance which is defined as the result or overall level of success of a person during a certain period to carry out the task compared with various possibilities, such as work standards, targets or targets or predetermined criteria and mutually agreed upon. Opinions about the performance of the teacher mentioned above are in line with Mangkunegara (2006) who says that work performance is the work of quality and quantity achieved by an employee in carrying out their duties in accordance with the responsibilities given to him (Muhlisin, 2010).

Education management cannot be separated from the model or style of leadership adopted by the principal in carrying out his role as a leader. The leadership style adopted by the principal will be related to the results and effectiveness of the principal in leading and carrying out the educational process in the school. As said by Glatthorn (2000) there is a strong attachment between the leadership style used by principals and the overall effectiveness of the educational process in schools. That is, reliable human resources cannot be separated from the influence of patterns or leadership styles that are applied in an organization, this will be reflected in the organization's implementation. A good leadership style will be seen in the way the wheels of the organization are orderly, comfortable, conducive, and in accordance with the desired goals.

Rivai (2014) states that Leadership style is a set of characteristics used by leaders to influence subordinates so that organizational goals are achieved or it can be said that leadership style is a pattern of behavior and strategy that is preferred and often applied by a leadership style leader who shows, directly or indirectly, it is about a leader's belief in the abilities of his subordinates.It means leadership style is behavior and strategy, as a result of a combination of philosophies, skills, traits, attitudes, which are often applied by a leader when he tries to influence the performance of his subordinates. Nawawi (2011) states leadership style is the 
behavior or method which chosen and used by leaders in influencing the thoughts, feelings, attitudes and behavior of members of the organization or subordinates. A person who occupies a leadership position has the capacity to read the situation that will be faced and adjust his leadership style to suit the demands of the situation he is facing, even though this adjustment is only temporary.

The principal's leadership style is very influential and crucial to the progress of the school. A balanced portion of these leadership styles will encourage the creation of work performance or productivity among teachers (Syahrial, 2013). The existence of a variety of principal leadership styles, is expected to be able to be an agent of change in the school so that it has an active role in improving the quality of education. A school principal must be a role model, both for teachers and their character as well as students and parents.

Teacher's work motivation is characterized by professionalism which is reflected in all teacher's activities in carrying out their duties and responsibilities. Highly motivated teachers will see the various shortcomings in the school as a challenge. The teacher will make every effort to overcome the shortcomings. With the good attention to the teacher, it will be able to cause the motivation of the teachers to do their best in doing the task, so that fostering commitment in doing quality work and is responsible for the progress of the organization (Dewi, 2015).

Siagian (2008) work motivation is a driving force that results in an employee willing and willing to move the ability to form the expertise and skills of his staff and time to carry out various activities that are his responsibility and fulfill obligations in order to achieve the goals and objectives of the company that have predetermined.

According to Wibowo (2014) work motivation is the desire to act. Everyone can be motivated by several different strengths. Work motivation is the result of a collection of internal and external forces that cause work to choose the right path of action and use certain behaviors. The low of teachers work motivation is the most frequently discussed issue in human resource management in the education sector. According to Suwarno (2012) there are currently many teachers who have not been able to work optimally with students because there are still many teachers who often arrive late, teachers leave students during class and only give assignments, lack of teachers' ability to use the media as learning material.

Based on the description above, this study aims to describe the leadership style, work motivation on the performance of high school teachers in Air Kumbang District, Banyuasin Regency. To prove and analyze the influence of leadership style and work motivation on the performance of high school teachers in Air Kumbang District, Banyuasin Regency.

Research related to leadership style and work motivation on teacher performance has been done by several previous researchers. Pujiyanti \& Isroah (2013) through her research entitled "The Effect of Work Motivation and Work Discipline on Teacher Performance in SMA Negeri 1 Ciamis proves that there is a positive and significant influence of work motivation on teacher performance. Al Hadromi (2017) with the title of his research Analysis of the Effect of Principal Leadership Style on Motivation, Discipline and Teacher Performance in Lumajang Islamic Elementary School found that the motivation of teacher performance had a significant effect on teacher performance. Hafid (2017), with the title of his research Influence of Teacher Motivation and Competence on School and Madrasah Teacher 
Performance in Salafiyah Islamic Boarding School Environment Syafi'iyah Sukorejo found that there was a positive and significant effect between work motivation on teacher performance.

\section{B. Methods}

Conducting this study, the research design used to determine the effect of leadership style and work motivation on teacher performance is hypothesis testing research. This study uses quantitative research method and research design in the form of influence studies, to determine the effect between two variables, namely the independent variable Leadership Style $\left(\mathrm{X}_{1}\right)$, Work Motivation $\left(\mathrm{X}_{2}\right)$ and the dependent variable teacher performance $(\mathrm{Y})$. This research was carried out in a high schools in Air Kumbang subdistrict, Banyuasin district. The population in this study were all high school teachers in Air Kumbang District of 85 people. Population is a generalization area that consists of objects that have certain qualities and characteristics determined by the researcher to be studied and then conclusions are drawn (Sugiyono, 2011).

\section{Results and Discussion}

SMA Negeri 1 Air Kumbang is located in Air Kumbang District, Kumbang Village Padang Permata, Jalan SP3 Banyuasin Regency. Status of ownership belongs to the Provincial Government. SMAN 1 Air Kumbang is the only public high school in Air Kumbang subdistrict formed under Air Kumbang I High School. It was established in 2012. Decree on establishment of school number. 172 of 2012 dated July 4, 2012. Operational Permit Letter of Statement number. 172 of 2012, July 4, 2012.

SMA Puspita is a high school which located on Jalan Inpres IV Hamlet Cintamanis Baru KM XI, Cinta Manis Baru, Air Kumbang District, Kab. Banyuasin, South Sumatra Province. Ownership status is the property of the Foundation. SMA Puspita was established in 1999, and began operating in 2000. School establishment decree No. 10/YPP/SMU/CMB/VII/99 dated July 1, 1999. Operating Permit Letter of Acceptance Number 417/III.07/KP/2000 dated February 9, 2000.

SMA Bima Bangsa is located at JalanPustu Desa Sido Makmur, Sido Makmur, Kec. Water beetles Kab. Banyuasin, South Sumatra Province. Ownership status is the property of the Foundation. SMA Bima Bangsa was founded in 1994, and began operating in 1994. This research was conducted by distributing questionnaires in the form of goegleforms which were distributed at SMA 1 Air Kumbang, SMA Puspita, and SMA Bima Bangsa in Air Kumbang District, Banyuasin Regency.

In the leadership style variable, the majority of respondents stated often (48.6\%) and $31.3 \%$ of respondents states very often towards the leadership style statement. Overall, the average respondent's response was in the frequent category (79.9\%) with an average score of 4.0 against statements on indicators for leadership style variables. Thus, high school teachers in Air Kumbang sub-district show a positive attitude towards all statements on the indicators for leadership style variables.

On the variable of work motivation, most respondents stated frequently (25.7\%) and $41.9 \%$ stated very often and overall respondents' response were in the frequent category $(67.6 \%)$ 
Volume 1 (2) 2020

E-ISSN: 2723-6919

with an average score of 3.9 to the statement for work motivation variable. Thus, high school teachers in Air Kumbang sub-district show a positive attitude towards all statements on the indicators for work motivation variables.

On the teacher performance variable, most respondents answers frequently $(57.4 \%)$ and $20.6 \%$ of respondents state very often and overall respondents' responses were in the frequent category $(80 \%)$ with an average score of 3.9 to all statements on indicators for teacher performance variables. Thus, high school teachers in Air Kumbang District show a positive attitude towards all statements on the indicators for teacher performance variables.

\section{Hypothesis Testing Results \\ Effect of Leadership Style on Teacher Performance}

Teacher performance in this study is the achievement that achieved by high school teachers in Air Kumbang District in carrying out their duties or work during a certain period according to the competency standards and criteria set for the job.

Table 1 Test Results of Leadership Style Variables

\begin{tabular}{|ll|c|c|}
\hline \multicolumn{2}{|l|}{ Model } & $\mathrm{T}$ & Sig. \\
\hline \multirow{2}{*}{1} & (Constant) & 2,039 & 0,045 \\
& Leadership style & 4,369 & 0,000 \\
\hline
\end{tabular}

a. Dependent Variable: Teacher Performance

T-test is conducted by comparing the value of sig. and the coefficients in table 1 above with the $t$-table value and the probability level of 0.05 . It is known t-table of 1.98896 obtained from Table $\mathrm{t}$ with $\mathrm{df}=85-2(\mathrm{df}=85-2, \mathrm{df}=83)$ and alpha 0.05 . The results of this study found that Hypothesis $\mathrm{H} 01$ was rejected and the Ha1 Hypothesis was accepted or in other words, the variable of leadership style individually influenced the performance of high school teachers in Air Kumbang District so that this meant, if the leadership style of the principal was improved then the performance of high school teachers in Air Kumbang District will also increase and vice versa if the leadership style decreases, then the performance of teachers will also decrease.

\section{The Effect of Work Motivation on Teacher Performance}

Teacher performance is the result achieved by a teacher in carrying out the tasks assigned to him. 
Table 2 Test Results Variable Work Motivation

\begin{tabular}{|cc|c|c|}
\hline \multicolumn{2}{|c|}{ Model } & T & Sig. \\
\hline \multirow{2}{*}{1} & (Constant) & 2,039 & 0,045 \\
& Job_Motivation & 2,094 & 0,039 \\
\hline
\end{tabular}

a. Dependent Variable: Teacher Performance

The results of the t-test for work motivation (X2) on teacher performance (Y) show a sig value of 0.039 , it means that the significance value is smaller than the probability value of $0.05(0.039<0.05)$ and the $t$ value shows a value of 2.094 , meaning that the $t$ value $>t$-table (2.094>1.98896).

Then the conclusion is that $\mathrm{H} 02$ is rejected and $\mathrm{Ha} 2$ is accepted, so it can be said that work motivation individually or partially has a positive and significant effect on teacher performance. Thus, if the work motivation increases, the teacher's performance will also increase and vice versa if the work motivation decreases, the teacher's performance will also decrease. In this study, the results of the partial test ( $t$ test) of the variable work motivation on performance found that there was a positive and significant effect of work motivation on the performance of high school teachers in Air Kumbang sub-district with a sig. Smaller than the probability value and $t$ count is greater than $t$ table.

\section{The Effect of Simultaneous Leadership Style and Work Motivation on Teacher Performance}

The simultaneous test results for the variable leadership style and work motivation on teacher performance

Table 3 Simultaneous Significance Test Results (Test F)

ANOVA ${ }^{b}$

\begin{tabular}{|ll|l|l|}
\hline Model & & F & Sig. \\
\hline 1 & Regression & 13,542 & $.000^{\mathrm{a}}$ \\
\hline
\end{tabular}

a. Predictors: (Constant), Work_motivation, leadership_style

b. Dependent Variable: Teacher_Performance

From the ANOVA test or F test, the F count was obtained 13,542 with a significance level of 0,000 . F-table 3.96 is obtained by looking at Table $\mathrm{F}$ with degrees $\mathrm{df}=\mathrm{k}-1(\mathrm{df}=2-1)$ and $\mathrm{f}=$ $\mathrm{n}-\mathrm{k}(\mathrm{df}=85-2)$ at the 0.05 significance level. Because the probability $(0,000)$ is much smaller than 0.05 and Fcount> Ftable (13.542> 3.96), this shows that H03 is rejected and Ha3 is 
accepted or in other words, leadership style variables and work motivation jointly affect teacher performance so this means that the performance of high school teachers in Air Kumbang District can be explained significantly by the variables of leadership style and work motivation.

The results showed that Hypothesis $\mathrm{H}_{03}$ is rejected and Hypothesis $\mathrm{H}_{\mathrm{a} 3}$ is accepted or in other words, the variables of leadership style and work motivation simultaneously affect the performance of high school teachers in Air Kumbang District so this means, if the leadership style and work motivation of the teacher increases, the performance teachers will also increase and vice versa if the leadership style and teacher work motivation decrease, then teacher performance will also decrease.

Based on the test of the coefficient of determination in this study, it was found that $24.8 \%$ of the performance of high school teachers in Air Kumbang District could be explained by their leadership style and work motivation. The results of the analysis carried out were still $75.2 \%$ of the variations that occurred in teacher performance could be explained by other factors besides the leadership style of the principal and work motivation which were not analyzed in this study, such as the ability of teachers to develop their professionalism, the availability of supporting facilities. needed in the learning process, moral and material support from school leaders, compensation, and others.

In order to achieve the learning objectives so as to produce quality students, high school teachers in Air Kumbang District need guidance, encouragement, and direction from the principal shown through his nurturing leadership style, not only as a school personification figure, but also understanding the goals of education. having a vision of the future and being able to actualize all the potential that exists that becomes a synergizing force to achieve educational goals.

Apart from the leadership style of the principal, optimal teacher performance can also be obtained through encouragement from within or from outside the teacher himself. Encouragement from within the teacher can be in the form of a teacher's sense of responsibility in carrying out assignments, carrying out tasks with clear targets, having clear and challenging goals, having feedback on the results of their work, having a feeling of pleasure at work, always trying to outperform others, give priority to the achievement of what is done. And encouragement from outside the teacher can be an effort to meet the needs of life and work needs, the pleasure of getting praise from the work done, the hope of wanting to get incentives, and the hope of getting attention from friends and superiors.

As professional teachers in the field of education, teachers must have the drive to always strive to develop their abilities against various innovations in learning activities, make improvements and adjustments to developments in science and technology, and seek solutions to various problems faced in learning. Encouragement from outside the teacher, apart from being obtained through encouragement from the principal, can also be obtained through the existence of various facilities or supporting infrastructure in carrying out the learning process that is relevant to the learning material, as well as learning tools and media to support and facilitate students' understanding of material taught.

The teacher also always tries to find and find the best learning models, but all of this really depends on the availability of supporting facilities needed in the learning process. In fostering 
and developing the performance of a teacher, moral and material support is a very determining factor. Giving motivation and appreciation from school leaders for the various efforts of teachers to improve professionalism, will have a positive impact in developing teacher interest and work activities. In addition, the provision of various learning tools according to the needs of teachers in each subject will further motivate teachers to do their best in achieving the learning objectives that have been set.

Through the leadership style of the school principal, the principal has a very high standard of moral and ethical behavior, and can be relied on to do the right thing so that it can be described as leader behavior that creates a sense of admiration, respect and at the same time trusting the leader in his followers. The charisma possessed by the principal is an important component of the leadership style. Teachers will have confidence and trust control under a charismatic school principal. Through charisma, in addition to arousing respect, the principal can inspire loyalty and perseverance, as well as instill pride and loyalty.

One of the other abilities the principal must have in his leadership style is the ability to motivate the teachers he leads. The principal as a leader must be able to communicate high expectations for the performance of teachers, inspire them through motivation to be loyal, and be part of a shared vision in the educational unit. Team spirit is enhanced, principals use symbols and emotional appeal to focus teachers' efforts in carrying out assignments.

Through intellectual stimulation, principals stimulate teachers to be creative and innovative and stimulate belief in values, it encourages teachers to develop innovative ways to deal with organizational problems and engage in careful decision making. Intellectual stimulation is an attempt by teachers to solve problems and influence teachers to see these problems through a new perspective.

One tangible form of the principal's leadership style is that the principal can give and show his attention and concern to the teachers he leads by holding regular meetings or meetings with teachers and administrative staff talk about school progress, especially discussing about improvement of teacher performance with regard to the program, implementation and results of the achievement of the implementation of supervision. This can increase the motivation of teachers in carrying out their duties, including in preparing Learning Implementation Plans (RPP), so that no more teachers do not make RPP. Gives the impression that there is not too far a distance in the relationship between the teacher and the principal, especially high school teachers in Air Kumbang District, so that no more teachers are reluctant or lazy to deal with the principal, so when the teacher has a problem, both in terms of learning or with students can be communicated with the principal. In terms of making decisions about a problem, the principal is also expected not to face difficulties in making decisions correctly and in a balanced manner, not to appear hasty in acting. This will not happen if the school principal has a leadership style favored by the teacher in improving teacher performance.

Thus, the principal's leadership style and teacher work motivation are very important factors in efforts to improve teacher performance. High school teachers in Air Kumbang District in particular should have given high performance by carrying out their duties and functions in educating students by carrying out learning in class well. Given the descriptive results of the research statistics found that the leadership style and work motivation of high school teachers in Air Kumbang District were classified as high, so that it would have an impact on high teacher performance. Teachers who have low performance, and who have often been called 
upon and received guidance from the principal, must show significant changes in the teacher's attitude.

\section{Conclusion}

There is a positive and significant influence between leadership style on the performance of high school teachers in Air Kumbang District, Banyuasin Regency with a sig value of 0.000 is smaller than the probability value of 0.05 and tcount greater than t table (4.369>1.98896). There is a positive and significant influence between work motivation on the performance of high school teachers in Air Kumbang District, Banyuasin Regency with a sig value of 0.039 which is smaller than the probability value of 0.05 and tcount greater than t table (2.094> 1.98896). There is a positive and significant influence between leadership style and work motivation simultaneously on the performance of SMA teachers in Air Kumbang District, Banyuasin Regency with a sig value. 0.000 is less than 0.05 and Fcount is greater than Ftable (13.542> 3.96).

\section{E. Acknowledgement}

We would like to express our special thanks and gratitude to Principal SMA Negeri 1 Air Kumbang, Rector Universitas PGRI Palembang, Director of Graduate Program Universitas PGRI Palembang and Study Program of Educational Management Universitas PGRI Palembang who gave us the support to do this wonderful project. This project was funded independent. Secondly, we would also like to thank our friends in Educational Management who helped us a lot in finalizing this project within the limited time frame.

\section{References}

Al Hadromi, F. (2017). Analisis Pengaruh Gaya Kepemimpinan Kepala Sekolah Terhadap Motivasi, Kedisiplinan dan Kinerja Guru di SD Islam Lumajang [Analysis of the Influence of the Principal's Leadership Style on Motivation, Discipline and Teacher Performance at SD Islam Lumajang]. BISMA: Jurnal Bisnis dan Manajemen, 11(1), 109-123.

Dewi, S. R. (2015). Peran Kepemimpinan Transformasional Terhadap Peningkatan Efektivitas Coaching [The Role of Transformational Leadership in Increasing Coaching Effectiveness]. JBBE, 8, 1-10.

Glatthorn, A., \& Randy, L. J. (2000). Writing the Winning Thesis or Dissertation a Step by Step Guide, California: Corwin Press.

Hasan, A. (2003). Meningkatkan Profesionalisme Guru [Increase Teacher Professionalism]. Jurnal Pendidikan. Jakarta: Diknas.

Hafid, M. (2017). Pengaruh Motivasi dan Kompetensi Guru Terhadap Kinerja Guru Sekolah dan Madrasah di Lingkungan Pondok Pesantren Salafiyah Syafi'iyah Sukorejo [The Effect of Teacher Motivation and Competence on the Performance of School and Madrasah Teachers in the Salafiyah Syafi'iyah Sukorejo Islamic Boarding School]. Jurnal Pendidikan Islam Indonesia, 1(2), 293-314. 
Journal of Social Work and Science Education

Volume 1 (2) 2020

E-ISSN: $2723-6919$

Handayani, Esti (2020). Pengaruh Budaya Organisasi Dan Gaya Kepemimpinan Kepala Sekolah Terhadap Kinerja Guru Di Kecamatan Muara Padang [The Influence of Organizational Culture and Principal Leadership Style on Teacher Performance in Muara Padang District]. Thesis Universitas PGRI Palembang.

Kristiawan, M., Safitri, D., \& Lestari, D. (2018). Manajemen Pendidikan [Educational Management]. Yogyakarta: Depublish.

Mangkunegara, A. P. (2006). Evaluasi Kinerja SDM [HR Performance Evaluation]. Jakarta: Eresco.

Muhlisin. (2008). Profesionalisme Kerja Guru Menyongsong Masa Depan [Teacher Work Professionalism Towards the Future]. https://www.academia.edu/6241931/Profesionalisme_kinerja_guru_masa_depan

Nawawi, H. (2011). Manajemen Sumber Daya Manusia [Human Resource Management]. Yogyakarta: Gadjah. Mada University Press.

Rivai, V. (2005). Manajemen Sumber Daya Manusia untuk Perusahaan dari Teori ke Praktik [Human Resource Management for Companies from Theory to Practice]. Jakarta: PT Raja Grafindo Persada.

Rivai, V. (2014). Manajemen Sumber Daya Manusia untuk Perusahaan [Human Resource Management for Companies]. Depok: PT. Raja Grafindo Persada.

Pujiyanti, P., \& Isroah, I. (2013). Pengaruh Motivasi Kerja dan Disiplin Kerja Terhadap Kinerja Guru SMA Negeri 1 Ciamis [The Effect of Work Motivation and Work Discipline on Teacher Performance in SMA Negeri 1 Ciamis]. Kajian Pendidikan Akuntansi Indonesia, 2(1).

Siagian, S. (2002). Kepemimpinan Organisasi \& Perilaku Administrasi [Organizational Leadership \& Administrative Behavior]. Jakarta: Gunung Agung.

Sugiyono. (2011). Metode Penelitian Kuantitatif dan $R$ dan $D$ [Quantitative Research Methods and $R$ and $D$ ]. Bandung: Alfabeta

Syahrial, S. (2013). Dasar-Dasar Sosiologi [Sociology Basics]. Yogyakarta: Graha Ilmu.

Suwarno., \& Donni, J. P. (2012). Manajemen SDM dalam Organisasi [HR Management in Organizations]. Publik dan Bisnis.

Undang-Undang Republik Indonesia [Law of Republic Indonsia]. (2003). Number 20 of 2003.

Undang Undang Republik Indonesia [Law of Republic Indonesia. (2005). Number 14 of 2005

Wibowo. (2014). Manajemen Kinerja [Work Management]. Jakarta: Rajawali Pers. 